\title{
Adsorption of Salivary Proteins to the Surface of Oral Streptococcal Cells
}

\author{
Muneaki Tamura, Toshiya Hara, Takayoshi Shibuya, Hideyoshi Oguma, Yasuyuki Hirano and \\ Kunio Hayashi
}

(Received 13 July and accepted 31 August 1994)

Key words: Streptococcus sanguis, Streptococcus mitis, Streptococcus salivarius, salivary proteins, adsorption

\begin{abstract}
Oral tissues, especially tooth surfaces, are covered with a layer of salivary proteins. Oral bacterial cells that adsorb to salivary components accumulated on the tooth surface are, as a rule, covered with the same components, especially proteins. Thus, it is possible that the salivary proteins covering the bacterial cells are related to the adhesion of bacteria to oral tissues. The aim of this study was to clarify the mechanisms of adsorption of salivary proteins to the surface of Streptococcus sanguis, S. mitis and S. salivarius using an adsorption assay with salivary proteins labeled with tritiated formaldehyde. The results showed that salivary proteins adsorbed more to $S$. salivarius than to $S$. mitis, and least to $S$. sanguis. It was evident that hydrophobic bonding was involved in the adsorption of salivary proteins to the bacterial cells tested. The amount of salivary proteins adsorbed to $S$. mitis and S. salivarius was decreased by the presence of phosphate, that to $S$. sanguis was increased by the presence of a divalent cation such as $\mathrm{Ca}^{2+}$, and that to all bacteria tested was inhibited in different ways by the presence of sugars. The amount of salivary proteins adsorbed to $S$. sanguis and $S$. salivarius was reduced effectively by pretreatment of the cells with trypsin, chymotrypsin and papain. In the case of $S$. mitis, the amount of adsorbed salivary proteins was decreased by pretreatment of the cells with chymotrypsin only, and was increased by pretreatment with lipase. These results indicate that there are different mechanisms of adsorption of salivary protein to the cell surfaces of oral streptococci.
\end{abstract}

\section{Introduction}

Dental caries and periodontal disease are caused by oral bacteria ${ }^{[1-4]}$, and therefore bacterial adhesion to the surface of oral tissues is observed in the early stage of these diseases. The mechanism of bacterial adhesion to oral tissues has been widely studied ${ }^{[5-15]}$, based mainly on just-harvested cultured bacterial cells. However, oral tissues such as teeth and the oral mucosa are quickly covered with a layer of salivary proteins, usually referred to as the acquired pellicle ${ }^{[16]}$.

At the same time, oral bacterial cells that adsorb to oral tissues are, as a rule, also covered with the same salivary pellicle. Thus it is possible that the salivary proteins covering the surface of oral bacteria are related to the adsorption of bacteria to oral tissues. In this respect, Tamura et al. ${ }^{[17]}$ pointed out nearly 6 years ago that differences in the number of bacterial cells adhering to salivary proteins on a membrane filter are observed between bacteria just-harvested from cultures and saliva-coated and that it was necessary for bacterial cells to be covered with body fluids when bacterial adhesion experiments were carried out ${ }^{[18-24]}$. For this reason, as a first step toward clarifying the relationship between salivary proteins which adsorb to oral bacteria and the adhesion of oral bacteria to oral tissues, this study was performed to clarify the mechanisms of adsorption of salivary proteins to the surface of several species of oral streptococcal cells, S. sanguis (strain ATCC 10556) which is present in high numbers in dental plaque ${ }^{[25,26]}$, S. mitis (strain ATCC 9811) which is

田村宗明、原俊哉、涉谷孝順、小熊秀佳、平野泰之: 林手雄

Department of Bacteriology, Nihon University School of Dentistry

To whom all correspondence should be addressed : Dr. Muneaki Tamura, Department of Bacteriology, Nihon University School of Dentistry, 1-8-13 Kanda-Surugadai, Chiyoda-ku, Tokyo 101, JAPAN 
detected mainly on the surface of the oral mucosa ${ }^{[25,26]}$, and S. salivarius (strain HHT) which is detected in saliva and on the dorsal tongue ${ }^{[25,26]}$, using an adsorption assay employing salivary proteins labeled with tritiated formaldehyde.

\section{Saliva collection and radiolabeling}

\section{Materials and Methods}

Whole unstimulated saliva from a single donor, aged 31y, blood type A, was collected in a container chilled in ice, then heated at $56^{\circ} \mathrm{C}$ for $60 \mathrm{~min}$ to inactivate any degradative enzymes ${ }^{[27]}$ and clarified by centrifugation at $8000 \times \mathrm{g}$ for $10 \mathrm{~min}$. Sodium azide was added at a final concentration of $0.04 \%$. The saliva was filtered ( Millipore, MA, U.S.A.), and dialyzed to remove inorganic substances. This preparation was finally lyophilized and stored at $-70^{\circ} \mathrm{C}$. Salivary proteins were dissolved in $0.067 \mathrm{M}$ potassium phosphate buffer (pH 7.5), and radiolabeled with $\left[{ }^{3} \mathrm{H}\right]$ formaldehyde ( Dupont NEN Research Products, MA, U.S.A. ) by reductive methylation as described by Jentoft ${ }^{28]}$.

\section{Bacterial strains and culture}

S. sanguis ATCC 10556, S. mitis ATCC 9811 and S. salivarius HHT were used throughout the study. They were grown overnight at $37^{\circ} \mathrm{C}$ in Todd-Hewitt broth (Difco, MI, U.S.A.) after preincubation with Todd-Hewitt semi-solid agar medium. Organisms were harvested at the late logarithmic phase by centrifugation at $3000 \times \mathrm{g}$ for $10 \mathrm{~min}$, washed twice in $0.05 \mathrm{M}$ Tris- $\mathrm{HCl}$ buffer $(\mathrm{pH} 7.0)$, and suspended in the same buffer. The suspension was vigorously forced back and forth through a 25-gauge syringe needle to break up the streptococcal chains ${ }^{[29]}$ and then standardized to an optical density of 0.5 at $550 \mathrm{~nm}$.

\section{Adsorption assay}

Bacterial pellets of $500 \mu \mathrm{l}$ of several bacterial suspensions were harvested by centrifugation at $4500 \times \mathrm{g}$ for $3 \mathrm{~min}$ in a polypropylene microtube ( Sarstedt, Rommelsdorf, Germany ). After addition of radiolabeled salivary proteins $\left(250 \mu \mathrm{g}\right.$ per $10^{9}$ cells for S. sanguis, $100 \mu \mathrm{g}$ for S.mitis and $150 \mu \mathrm{g}$ for S.salivarius ${ }^{[2,24]}$ ) at $-4^{\circ} \mathrm{C}$ for $60 \mathrm{~min}$, the bacterial cells were washed three times in Tris- $\mathrm{HCl}$ buffer in the tubes to remove residual salivary proteins by centrifugation at $4500 \times \mathrm{g}$ for $3 \mathrm{~min}$. The specific radioactivity of the labeled salivary proteins was counted. At the same time, the final cell number in each tube was counted to determine the volume of salivary proteins adsorbed per $10^{9}$ cells.

Effect of divalent cations, phosphate, and surface-active agent on adsorption of salivary proteins to bacterial surfaces

To test the effect of divalent cations on the adsorption of salivary proteins to bacterial cell surfaces, the amounts of adsorbed salivary proteins were measured using Tris- $\mathrm{HCl}$ buffer containing either $\mathrm{Ca}^{2+}$ or $\mathrm{Mg}^{2+}$ at concentrations of 10 or $100 \mathrm{mM}$. The effect of phosphate on the adsorption was compared when Tris- $\mathrm{HCl}$ buffer and potassium phosphate buffer at $\mathrm{pH} 7.0$ were used. To test the effect of a surface-active agent on the adsorption, the amounts of adsorbed salivary proteins were measured using Tris- $\mathrm{HCl}$ buffer containing $0.1 \%$ Tween 80 for examining relationship between hydrophobic binding and salivary protein adsorption.

\section{Effect of sugar on adsorption of salivary proteins to bacterial surfaces}

To examine the lectin binding on the adsorption of salivary proteins to bacterial cells, the organisms were incubated in Tris- $\mathrm{HCl}$ buffer containing $1 \mathrm{mM} \mathrm{CaCl}_{2}^{[30,31]}$, and either 10 or $100 \mathrm{mM}$ of sugars such as L-fucose, D-mannose, D-galactose, lactose, D-glucose, N-acetyl-D-galactosamine or N-acetyl-D-glucosamine.

\section{Pretreatment of bacterial cells with enzymes}

The influence of pretreatment of bacterial cells with several enzymes on the adsorption of salivary proteins to the cell surface was studied. The enzymes used were trypsin (Gibco, NY, U.S.A.; pH 8.0 ), chy- 
motrypsin (Wako Pure Chemical, Osaka, Japan ; pH 8.0 ), papain (Wako ; pH 6.0 ) and lipase (Wako ; pH 9.0 ) at $37^{\circ} \mathrm{C}$ for $30 \mathrm{~min}$ (control consisted of non-treated bacterial cells suspended in potassium phosphate buffer $)^{[22,23]}$. After treatment with each enzyme, the bacterial cells were washed three times in Tris- $\mathrm{HCl}$ buffer by centrifugation at $3000 \times \mathrm{g}$ for $10 \mathrm{~min}$ to remove residual enzymes, and were restandardized in the buffer, and the amount of adsorbed protein was assayed. The amounts of salivary proteins adsorbed to bacteria at $\mathrm{pHs}$ shown above were employed as controls ${ }^{[22,24]}$.

\section{Results}

Amounts of salivary proteins adsorbed to bacterial surfaces

The results are presented in Table 1 . The amounts of salivary proteins adsorbed to the bacterial cell surfaces were $898.4 \mathrm{ng}$ for $S$. sanguis, 1,000.7 $\mathrm{ng}$ for $S$. mitis, and 2,887.7 $\mathrm{ng}$ for $S$. salivarius. This table shows that differences in the affinity of salivary proteins for the bacterial surface are evident.

Table 1 Amounts of salivary proteins adsorbed to bacterial surfaces ( ng/109 cells)

\begin{tabular}{llr}
\hline Streptococcus sanguis & ATCC 10556 & $868.4(74.7)^{*}$ \\
Streptococcus mitis & ATCC 9811 & $1000.7(106.1)^{*}$ \\
Streptococcus salivarius & HHT & $2887.7(339.1)^{*}$ \\
\hline
\end{tabular}

Table 2 Effect of divalent cations, phosphate, and surface-active agent on the adsorption of salivary proteins to bacterial surfaces ( $\%$ adsorption of salivary proteins compared to the control)

\begin{tabular}{lrccc}
\hline & & S. sanguis & S. mitis & S. salivarius \\
\hline Control & & 100 & 100 & 100 \\
$\mathrm{CaCl}_{2}$ & $1 \mathrm{mM}$ & 133.9 & 128.3 & 81.7 \\
& $10 \mathrm{mM}$ & 134.7 & 81.5 & 66.6 \\
$\mathrm{MgCl}_{2}$ & $1 \mathrm{mM}$ & 98.6 & 86.2 & 83.7 \\
& $10 \mathrm{mM}$ & 100.0 & 84.8 & 68.1 \\
Phosphate & 97.2 & 84.7 & 66.9 \\
Tween 80 & 39.3 & 42.1 & 57.9 \\
\hline
\end{tabular}

Effect of divalent cations, phosphate, and surface-active agent on adsorption of salivary proteins to bacterial surfaces

The results are shown in Table 2. The amount of salivary proteins adsorbed was increased by the presence of $\mathrm{Ca}^{2+}$ for $S$. sanguis and by the presence of $1 \mathrm{mM} \mathrm{Ca}^{2+}$ for $S$. mitis, but the amount was decreased by both $\mathrm{Ca}^{2+}$ and $\mathrm{Mg}^{2+}$ for $S$. salivarius and by $\mathrm{Mg}^{2+}$ and $10 \mathrm{mM} \mathrm{Ca}^{2+}$ for $S$. mitis. Phosphate inhibited the adsorption of salivary proteins to S.mitis and S.salivarius, but not to S.sanguis. For all bacterial cells, the amount of adsorbed salivary proteins was lowest in the presence of the surface-active agent Tween 80 .

\section{Effect of sugars on adsorption of salivary proteins to bacterial surfaces}

The results are given in Table 3. The presence of lactose and N-acetyl-D-glucosamine inhibited the adsorption of salivary proteins to all bacterial cell surfaces, and the presence of L-fucose, D-mannose and Dgalactose inhibited the adsorption to $S$. sanguis and S. mitis. The presence of D-glucose affected the adsorption to $S$. sanguis, but not to other strains. In the case of $S$. mitis and S. salivarius, the amounts of adsorbed salivary proteins were increased by the presence of $\mathrm{N}$-acetyl-D-galactosamine. 
Table 3 Effect of sugars on the adsorption of salivary proteins to bacterial surfaces

( \% adsorption of salivary proteins compared to the control)

\begin{tabular}{lcccc}
\hline & & S. sanguis & S. mitis & S. salivarius \\
\hline Control & & 100 & 100 & 100 \\
L-fucose & $10 \mathrm{~m} \mathrm{M}$ & 71.3 & 65.2 & 95.3 \\
& $100 \mathrm{~m} \mathrm{M}$ & 65.3 & 71.2 & 93.2 \\
D-mannose & $10 \mathrm{~m} \mathrm{M}$ & 95.4 & 92.7 & 101.2 \\
& $100 \mathrm{~m} \mathrm{M}$ & 72.2 & 78.4 & 90.8 \\
D-galactose & $10 \mathrm{~m} \mathrm{M}$ & 90.5 & 80.7 & 95.6 \\
& $100 \mathrm{~m} \mathrm{M}$ & 79.0 & 80.0 & 90.6 \\
Lactose & $10 \mathrm{~m} \mathrm{M}$ & 94.4 & 74.0 & 84.5 \\
& $100 \mathrm{~m} \mathrm{M}$ & 67.3 & 64.3 & 86.4 \\
D-glucose & $10 \mathrm{~m} \mathrm{M}$ & 85.0 & 116.8 & 106.1 \\
& $100 \mathrm{~m} \mathrm{M}$ & 66.4 & 95.6 & 158.8 \\
N-acetyl-D-galactosamone & & & 363.2 \\
& $10 \mathrm{~m} \mathrm{M}$ & 92.0 & 132.5 & \\
N-acetyl-D-glucosamine & $100 \mathrm{~m} \mathrm{M}$ & 88.9 & 458.7 & 95.1 \\
& $10 \mathrm{~m} \mathrm{M}$ & 79.8 & 80.4 & 79.7 \\
\hline
\end{tabular}

Table 4 Effect of pretreatment of bacterial cells with enzyme on the adsorption of salivary proteins to bacterial surfaces ( \% adsorption of salivary proteins compared to the control)

\begin{tabular}{lccc}
\hline & S. sanguis & S. mitis & S. salivarius \\
\hline Control & 100 & 100 & 100 \\
Trypsin & 40.4 & 98.9 & 29.1 \\
Chymotrypsin & 46.5 & 81.5 & 23.1 \\
Control & 100 & 100 & 100 \\
Papain & 40.9 & 95.2 & 18.4 \\
Control & 100 & 100 & 100 \\
Lipase & 89.0 & 218.7 & 97.1 \\
\hline
\end{tabular}

\section{Effect of enzyme pretreatment on adsorption of salivary proteins to bacterial surfaces}

The results are given in Table 4. The amounts of adsorbed salivary proteins were decreased by pretreatment of the cells with trypsin, chymotrypsin, and papain for $S$. sanguis and S. salivarius. When S. mitis was used, the amount of proteins was decreased by chymotrypsin, and was increased by lipase.

\section{Discussion}

As dental caries and periodontal disease are caused by oral bacteria ${ }^{[1-4]}$, bacterial adhesion to the surface of oral tissues should be considered the first stage of these diseases. The surface of bacterial cells is covered with salivary proteins, like that of oral tissues, probably because the cells are suspended in saliva before bacterial adhesion to oral tissues, and thus it is possible that the cells' surface covered with salivary proteins is related to their adhesion to oral tissues.

As a first step toward clarifying the relationship between the salivary proteins adsorbed to bacterial 
cells and their adhesion to oral tissues, the aim of this study was to clarify the mechanisms of adsorption of salivary proteins to several oral streptococci using an adsorption assay with salivary proteins labeled with tritiated formaldehyde. The results showed that salivary proteins had higher affinity for $S$. salivarius than for S. mitis, and for S. mitis than for S. sanguis. It may be assumed that there is some relationship between the high salivary protein affinity for $S$. salivarius and the isolation of $S$. salivarius in high number from saliva in the oral cavity.

The mechanism of oral bacterial adhesion to oral tissues is divisible into two types ${ }^{[32]}$, non-specific and specific binding. Thus, we had investigated the relationship between these types of binding and the mechanisms of adsorption of salivary proteins to bacterial cells.

Non-specific binding is known to occur through several mechanisms including bridging divalent cations $^{[32]}$ and hydrophobic bonding ${ }^{[32,33]}$. As divalent cations are related to bacterial adhesion, the effect of $\mathrm{Ca}^{2+}$ or $\mathrm{Mg}^{2+}$ on the adsorption of salivary proteins to bacterial cells was examined. The results show that the effects of divalent cations are found to be diverse and that $\mathrm{Ca}^{2+}$ promotes the adsorption of salivary proteins to $S$. sanguis only.

To test for hydrophobic bonding ${ }^{[32,33]}$, a surface-active agent, Tween 80 , was added to the buffer. It is obvious that hydrophobic bonding plays a role in salivary protein adsorption, because the amount of adsorbed salivary proteins was greatly reduced by the addition of Tween 80 in all bacterial strains.

We also examined the effect of phosphate, which has a high affinity for $\mathrm{Ca}^{2+}$ and affects the formation of pellicle ${ }^{[32,34]}$, on the adsorption. The presence of phosphate was found to decrease the amount of salivary proteins adsorbed to $S$. mitis and $S$. salivarius, but not to $S$. sanguis . Thus the same mechanism may operate in both bacterial adhesion to oral tissues and adsorption of salivary protein to bacterial cells in the case of $S$. mitis and S. salivarius, but not in the case of $S$. sanguis.

With regard to lectin binding as a specific binding ${ }^{[28,34]}$, it has been reported that the latter is inhibited by addition of sugars ${ }^{[35]}$, and is dependent on the presence of divalent cations such as $\mathrm{Ca}^{2+}{ }^{[28,29]}$. Accordingly, the effects of sugars on the adsorption of salivary proteins to bacterial cells were examined in the presence of $1 \mathrm{mM} \mathrm{CaCl}_{2}$. The presence of sugars, such as lactose and $\mathrm{N}$-acetyl-D-glucosamine inhibited the adsorption of salivary proteins to all the bacterial cells examined, and the presence of L-fucose, D-mannose and Dgalactose inhibited the adsorption of salivary proteins to $S$. sanguis and $S$. mitis. These results suggest that lectinbinding is involved in the adsorption of salivary protein to bacterial cells, especially $S$. sanguis and S. mitis. When S. mitis and S. salivarius were used, however, the amounts of adsorbed salivary proteins were increased by the presence of $\mathrm{N}$-acetyl-D-galactosamine. This result differed from the previous reports [34-36]. We are unable to conclude how this sugar is related to the mechanism of adsorption of salivary proteins, and further studies will be needed to clarify this.

We then focused on the surface component of cells involved in the adsorption of salivary proteins to the bacteria. Experiments involving pretreatment of bacterial cells with enzymes were reported previously by Liljemark et al. ${ }^{[37]}$ We used a modification of these methods in this study. The results indicate that the surface proteins of $S$. sanguis and S. salivarius as well as the cell surface lipid of $S$. mitis play a very important role in the mechanism of adsorption of salivary protein to their cells.

\section{Conclusion}

There are several mechanisms involved in the adsorption of salivary proteins to the surfaces of oral bacteria, and doubtlessly there is some relationship between bacterial adhesion to oral tissues and the adsorption of salivary proteins to bacterial cells. These differences in adsorption mechanisms may be responsible for the differences in distribution of the bacteria within the oral cavity.

\section{Acknowledgments}

This research was supported in part by a research-aid fund from Nihon University and by a grant from the Sato Fund, Nihon University School of Dentistry. 


\section{References}

[ 1 ] Keyes, P.H.: The infectious and transmissible nature of experimental caries, Arch. Oral Biol., 1, 304320,1960

[2] Socransky, S.S., Hubersak, C. and Propas, D.: Induction of periodontal destruction in gnotobiotic rats by a human oral strain of Actinomyces naeslundii, Arch. Oral Biol., 15, 993-995, 1970

[ 3 ] Fitzgerald, R.J. and Keyes, P.H.: Demonstration of the etiologic role of streptococci in experimental caries in the hamster, J. Am. Dent. Assoc., 6, 9-19, 1960

[ 4 ] Jordan, H.V., Keyes, P.H. and Bellack, S.: Periodontal lesions in hamsters and gnotobiotic rats infected with actinomyces of human origin, J. Periodontol. Res., 7, 21-28, 1972

[ 5 ] Gibbons, R.J. and van Houte, J.: Selective bacterial adherence to oral epithelial surfaces and its role as an ecological determinant, Infect. Immun., 3, 567-573, 1971

[6] van Houte, J., Gibbons, R.J. and Banghart, S.B.: Adherence as a determinant of the presence of Streptococcus salivarius and Streptococcus sanguis on the human tooth surface, Arch. Oral Biol., 15, 1025-1034, 1970

[ 7 ] Appelbaum, B., Golub, E., Holt, S.C. and Rosan, B.: In vitro studies of dental plaque formation : Adsorption of oral streptococci to hydroxyapatite, Infect. Immun., 25, 717-728, 1979

[ 8 ] Wheeler, T.T., Clark, W.B. and Birdsell, D.C.: Adherence of Actinomyces viscosus T14V and T14AV to hydroxyapatite surfaces in vitro and human teeth in vivo, Infect. Immun., 25, 1066-1074, 1979

[9] Staat, R.H., Langley, S.D. and Doyle, R.J.: Streptococcus mutans adherence : Presumptive evidence for protein-mediated attachment followed by glucan-dependent cellular accumulation, Infect. Immun., 27, 675-681, 1980

[10] Weerkamp, A.H. and Mcbride, B.C. : Adherence of Streptococcus salivarius HB and HB-7 to oral surfaces and saliva-coated hydroxyapatite, Infect. Immun., 30, 150-158, 1980

[11] Cowman, R.A., Baron, S.J. and Fitzgerald, R.J.: Utilization of hydroxyapatite adsorbable salivary proteins as growth substrates for plaque-forming oral streptococci, J. Dent. Res., 60, 1803-1808, 1981

[12] Stinson, M.W., Levine, M.J., Cavese, J.M., Prakobphol, A., Murray, P.A., Tabak, L.A. and Reddy, M.S. : Adherence of Streptococcus sanguis to salivary mucin bound to glass, J. Dent. Res., 61, 13901393, 1982

[13] Eifert, R., Rosan, B. and Golub, E.: Optimization of an hydroxyapatite adhesion assay for Streptococcus sanguis, Infect. Immun., 44, 287-291, 1984

[14] Childs III, W. C. and Gibbons, R. J.: Use of percoll density gradient for studying the attachment of bacteria to oral epithelial cells, J. Dent. Res., 67, 826-830, 1988

[15] Gibbons, R. J.: Bacterial adhesion to oral tissues; A model for infectious diseases, J. Dent. Res., 68, 750-760, 1989

[16] Dawes, C., Jenkins, G. N. and Tonge, C. H.: The nomenclature of the integuments of the enamel surface of teeth, Br. Dent. J., 115, 65-68, 1963

[17] Tamura, M., Kudo, S., Kikuchi, K., Hirano, Y., Hayashi, K. and Kuwata, F.: Analysis of phenomenon of oral bacterial adhesion, Jpn. J. Oral Biol., 30(Suppl.), 201, 1988 (in Japanese )

[18] Tamura, M. : Adsorption of Streptococcus sanguis to proteins of parotid saliva, Nihon Univ. Dent. J., 65, 76-83, 1991 (in Japanese)

[19] Tamura, M., Kamata, T., Takao, K., Okada, H., Tanaka, H., Hirano, Y. and Hayashi, K.: Adsorption per unit amount of protein of Streptococcus sanguis and Streptococcus salivarius to parotid salivary proteins which removed from hydroxyapatite beads, Nihon Univ. Dent. J., 65, 499-503, 1991 (in Japanese )

[20] Tamura, M., Kudo, S., Hara, T., Shibuya, T., Kikuchi, K., Hirano, Y. and Hayashi, K.: Effect of pH and phosphate on adsorption of Streptococcus sanguis to parotid salivary proteins which removed from hydroxyapatite beads, Nihon Univ. Dent. J., 65, 566-571, 1991 (in Japanese)

[21] Tamura, M., Takao, K., Okada, H., Uchiyama, N., Miyamoto, H. and Hayashi, K.: Difference of salivary proteins attached to the surface of several oral bacterial cells, Nihon Univ.Dent. J., 66, 850-856, 
1992 (in Japanese)

[22] Tamura, M., Uchiyama, N., Miyamoto, H., Sekine, Y., Nemoto, Y., Hirano, Y. and Hayashi, K.: Analysis of phenomenon of oral bacterial cells adhere to the tooth surface [I] Mechanisms of adsorption of salivary proteins to the surface of Streptococcus sanguis ATCC 10556, Nihon Univ. Dent. J., 68, 120-127, 1994 (in Japanese)

[23] Tamura, M., Hara, T., Shibuya, T., Ueda, Y., Saito, N., Hirano, Y. and Hayashi, K.: Analysis of oral bacterial adhesion to the tooth surface [II] Analysis of components of salivary proteins adsorbed to the surface of Streptococcus sanguis ATCC 10556, Nihon Univ. Dent. J., 68, 253-261, 1994 (in Japanese)

[24] Tamura, M., Nouda, K., Matsumoto, K., Sekine, Y., Nemoto, Y., Hirano, Y. and Hayashi, K.: Analysis of oral bacterial adhesion to the tooth surface [III] Mechanisms of adsorption of salivary proteins to the surface of Streptococcus mitis ATCC 9811, Nihon Univ. Dent. J., 68, 818-825, 1994 (in Japanese,)

[25] Gibbons, R.J. and van Houte, J.: Bacterial adherence in oral microbial ecology, Ann. Rev. Microbiol., $29,19-44,1975$

[26] Hamada, S. and Hutton, D.S.: Biology, immunology, and cariogenicity of Streptococcus mutans, Microbial. Rev., 44, 331-384, 1980

[27] Gibbons, R.J. and Qureshi, J.V.: Selective binding of blood group-reactive salivary mucins by Streptococcus mutans and other oral organisms, Infect. Immun., 22, 665-671, 1978

[28] Jentoft, N. and Dearborn, D.G.: Labeling of proteins reductive methylation using sodium cyanoborohydride, J. Biol. Chem., 254, 4359-4365, 1979

[29] Gibbons, R.J., Moreno, E. C. and Spinell, D.M.: Model delineating the effects of a salivary pellicle on the adsorption of Streptococcus mitior onto hydoxyapatite, Infect. Immun.,14, 1109-1112, 1976

[30] Rohringer, R.J. and Holden, D.W.: Protein blotting; Detection of protein with colloidal gold, and of glycoproteins and lectins with biotin-conjugated and enzyme probes, Anal. Biochem., 144, 118-127, 1985

[31] Cisar, J. O., Kolenbrander, P. E. and McIntire, F. C. : Specificity of coaggregation reactions between human oral streptococci and strains of Actinomyces viscosus or Actinomyces naeslundii, Infect. Immun., 24, 792-752, 1979

[32] Rölla,G.: Inhibition of adsorption-general considerations. In Microbial Aspects of Dental Caries, II ,309324, Stiles, H. M., Loesche, W.L. and O’Brien, T. C. eds., Information retrieval, Washington, D.C., 1976

[33] Gibbons, R.J. and Etherden, I. : Comparative hydrophobicities of oral bacteria and their adherence to salivary pellicles, Infect. Immun., 41, 1190-1196, 1983

[34] Gibbons, R. J., Etherden, I. and Moreno, E. C. : Association of neuraminidase-sensitive receptors and putative hydrophobic interactions with high-affinity binding sites for Streptococcus sanguis C5 in salivary pellicles, Infect. Immun., 42, 1006-1012, 1983

[35] Gibbons, R.J. and Qureshi, J. V. : Inhibition of adsorption of Streptococcus mutans strains to salivatreated hydroxyapatite by galactose and certain amines, Infect. Immun., 26, 1214-1217, 1979

[36] Gibbons, R.J. and Etherden, I.: Enzymatic modification of bacterial receptors on saliva-treated hydroxyapatite surfaces, Infect. Immun., 36, 52-58, 1982

[37] Liljemark, W. F. and Schauer, S. V. : Studies on the bacterial components which bind Streptococcus sanguis and Streptococcus mutans to hydroxyapatite, Arch. Oral Biol., 20, 609-615, 1975 